\title{
Development Status and Prospects of China's Critical Basic Materials
}

\author{
Tu Hailing, Li Tengfei, Ma Fei
}

General Research Institute for Nonferrous Metals, Beijing 100088, China

\begin{abstract}
Critical basic materials are essential for the development of the manufacturing industry. They provide important support and protection for national economic development and defense construction. This paper describes the current status of critical basic materials in China as well as abroad and presents the challenges that are confronting domestic enterprises. Finally, the paper suggests government policies that will promote the development of critical basic materials.
\end{abstract}

Keywords: Critical basic materials; development status; policy suggestions

\section{Introduction}

Critical basic materials are essential for advanced industrial products and their production processes, and are the basis for the development of advanced manufacturing. Critical basic materials include but are not limited to materials which have a large number and wide range of applications but still need improvement, independently developed materials which affect economic security and national defense, and novel materials which lead to the development of advanced manufacturing and must be acquired in advance. The critical basic materials described in this paper include electronic information materials, new energy materials, novel chemical materials, new construction materials, steel materials for high-end heavy equipment, high-performance nonferrous and rare metal materials, inorganic non-metallic materials, special fiber materials, and biomedical and pharmaceutical materials.

In general, China's critical basic materials have made great progress after years of development. In addition, the level of core technology has improved significantly and the scale of industry has been expanded gradually. This development has provided strong support for the development of the national economy and construction of the national defense industry. However, the competitiveness of critical basic materials must be improved, as the product quality and reliability hardly meet the demand, and hence, dependence on imported critical material continues [1]. Therefore, it is necessary to strengthen the top-level design of critical basic material development and improve related policies and measures. This has important strategic significance for implementing the Made in China 2025 strategy, upgrading China's basic industrial capabilities, strengthening the defense industry, and accelerating the transformation of the economic development mode.

\section{Development status of China's critical basic materials}

2.1 constant improvement on macro policy environment for critical basic materials

Recently, the State Council, National Development and Reform Commission, Ministry of Industry and Information Technology, and Ministry of Science and Technology have issued a number of macro industrial development plans, such as the Decision of the State Council on Accelerating the Cultivation and Development of Strategic Emerging Industries, The 13th

Received date: April 16, 2017; Revised date: May 23, 2017

Corresponding author: Tu Hailing, General Research Institute for Nonferrous Metals, Honorary President; Chinese Academy of Engineering, Academician. E-mail:tuhl@grinm.com.

Funding program: CAE Advisory Project "Research on Industrial Foundation Strengthening Strategy" (2014-ZD-10).

Chinese version: Strategic Study of CAE 2017, 19 (3): 125-135

Cited item: Tu Hailing et al. Development Status and Prospects of China' Critical Basic Materials. Strategic Study of CAE, https://doi.org/10.15302/J-SSCAE-2017.03.018 
Five-Year Plan for Strategic Emerging Industries Development, Made in China 2025, Key Technology Roadmap of Made in China 2025, Industry Strength Foundation Project Implementation Guide (2016-2020), Guiding Opinions on Accelerating the Innovation and Development of New Material Industry, and The 13th Five-Year National Science and Technology Innovation Plan (Table 1) [2]. Moreover, these departments have issued specific development plans for different areas and further clarified the goals and tasks for critical basic materials development. These goals and tasks pertained to specific products, technologies, and equipment and have been implemented in major projects which lay the foundation for corporate decisions, government allocation of public resources, and healthy development of strategic emerging industries.

\subsection{Improved research level of critical basic materials}

The key to promoting industrial strength and improving competitiveness is improving the capacity for independent innovation and strengthening core technological breakthroughs. With production, education, and research over the last 20 years, breakthroughs in a large number of critical basic materials' core technologies have been achieved, and these R\&D achievements have been promoted and applied. These achievements significantly improved the core competitiveness of fields related to critical basic materials [2]. Large-diameter silicon materials continue to improve in terms of defects, geometric parameters, particles, and impurity control technologies. Dislocation-free $450 \mathrm{~mm}$ silicon monocrystalline material has been developed, and $300 \mathrm{~mm}$ silicon material could meet integrated circuit requirements for $45 \mathrm{~nm}$ nodes used in next-generation technologies [3]. Progress has also been made in artificial crystal materials over the last few years. The development of ultraviolet non-linear optical crystals, such as barium metaborate (BBO) and lithium triborate (LBO), has reached an advanced level and achieved commercialization internationally. Potassium fluoroborate (KBBF) is the only practically available deep-ultraviolet non-linear optical crystal to date that has been equipped successfully in advanced scientific instruments in China. The major technical advances in laser crystal technology such as for Nd:YAG, Nd:GGG, and Nd: $\mathrm{YVO}_{4}$ lasers, have reached an advanced international level and a kilowatt-class all-solid-state laser output has been produced [4]. Lithium-ion battery cathode/anode materials and electrolytes have been developed to meet the requirements of small batteries. In addition, local development of other key materials such as separators, electrolytes, and lithium salts have decreased the reliance on imports. The development of industrial materials, such as ultra-high molecular weight polyethylene fibers, halogenated butyl rubber, and high-performance flooding polymers, has narrowed the gap between China's chemical materials industry and those of developed countries. Submarine pipeline steels (X65, $\mathrm{X} 70$, and $\mathrm{X} 80$ ), thick-wall marine oil and gas pipelines, and chemical medium-strength plates are examples of advanced materials that have been domestically produced. The independently developed 2205 duplex stainless-steel has been used in chemical vessels. In addition, $9 \% \mathrm{Ni}$ steel has been used in liquefied natural gas ships and $12 \mathrm{Ni} 19$ steel for liquefied ethylene storage tanks has been mass produced. Next-generation aluminum alloy materials with high strength, toughness, and hardenability and rapidly solidified spray-deposited aluminum alloy materials with strength greater than $800 \mathrm{MPa}$ have achieved excellent performance on an international level [5]. Value-added preparation technologies for copper materials such as copper strips, brass casts, and copper-aluminum composites have been developed and patented. The performance of submicron ultrafine carbide cutting tools has also reached a world-class level. Steel with yield strength of $355 \mathrm{MPa}$ is domestically produced and accounts for $90 \%$ of the steel used in steel platforms. Significant progress has been made in the development and production of large titanium alloy ingots and forgings, and the technology for titanium alloy material development and processing of large-size titanium alloy materials has significantly improved [6]. C194, KFC, and C7025 electronic lead frame copper tapes represent key technological breakthroughs for industrialization and have reached a 10,000-ton production scale. Stable production of T300-grade carbon fiber has been achieved with increased single-line production capacity of 1200 tons, and T700-grade high-performance carbon fiber is now produced using the dry-jet wet spinning process. The key equipment for these processes has been independently designed and manufactured, which has significantly reduced production costs of these materials. The performance of basalt fiber, polyphenylene sulfide fiber, and other products has reached an advanced level. China issued the National Standard for Electromagnetic Metamaterials and developed a new satellite communication product based on metamaterials and super-radio technology, as shown in Fig. 1. Two-dimensional materials, such as graphene-related materials, have been used in the applications shown in Fig. 2 [7,8].

\subsection{Rapidly expanding production of critical basic materials}

In recent years, the new materials industry has rapidly developed as a strategic emerging industry. The industry scale has grown from 650 to 25,000 billion yuan from 2010 to 2016 (Table 2), with an average annual growth rate of approximately $25 \%$ [9]. Among the key basic materials, the output of rare earth metals ranks first in the world, with a total export volume of 47,227 tons in 2016, a year-over-year increase of $35.6 \%$ [10]. The output value of semiconductor silicon materials reached 5.3 billion yuan in 2015, which was a $60 \%$ increase compared to 2010 and accounted for approximately $5 \%$ of the global market share. The research and application of membrane materials has developed rapidly. The total output value of the membrane treatment industry reached 84.9 billion yuan in 2015 , an increase of $15.8 \%$ over 
Table 1. China's critical basic materials industry development plans.

\begin{tabular}{ll}
\hline Year & Development plans \\
\hline 2010 & $\begin{array}{l}\text { Decision of the State Council on Accelerating the Cultivation and } \\
\text { Development of Strategic Emerging Industries }\end{array}$ \\
2011 & $\begin{array}{l}\text { Guidelines for Priority Areas for High-tech Industrialization Prior to } \\
\text { Development (2011) }\end{array}$
\end{tabular}

2011 National 12th Five-Year Plan

2012 New Material Industry 12th Five-Year Plan

The 12th Five-Year Plan for Semiconductor Lighting Technology Development, The 12th Five-Year Plan for High-Quality Special Steel Technology Development, The 12th Five-Year Plan for High Performance Membrane Materials, The 12th Five-Year Plan for Medical Device Technology Industry, The 12th Five-Year Plan for Non-ferrous Metals Industry, Energy Saving and New Energy Automobile Industry Development Plan (2012-2020)

2013 National Integrated Circuit Industry Development Program, Energy Development 12th Five-Year Plan, Suggestions on Accelerating the Development of Energy-Saving and Environmental Protection Industries, Air Pollution Prevention Action Plan, State Council's Opinions on Promoting Healthy Development of Photovoltaic Industry

2014 Guiding Opinions on Accelerating the Popularization and Application of New Energy Vehicles, Critical Material Upgrade Project Implementation Plan.

$2015 \quad$ Made in China 2025

2016 Guiding Opinions on Accelerating the Innovation and Development of New Materials Industry

Notice on Implementing Manufacturing Upgrades and Renovation of Major Engineering Packages.

The 13th Five-Year National Science and Technology Innovation Plan

The 13th Five-Year National Strategic Emerging Industry Development Plan

Fields involving new materials

High-performance composite materials, advanced structural materials, and novel functional materials.

Nanomaterials, special materials for nuclear engineering, special fiber materials, membrane materials and components, special functional materials, and rare earth materials.

Novel functions and smart materials, advanced structures and composite materials, nanomaterials, novel electronic functional materials, high-temperature alloy materials, highperformance fibers and composite materials, and advanced rare earth materials.

Special metal functional materials, high-end metal structural materials, advanced polymer materials, novel inorganic nonmetallic materials, high-performance composite materials, and cutting-edge materials.

Semiconductor lighting materials, high quality special steel materials, novel lightweight alloys, membrane materials, biomedical materials, and lithium-ion battery materials.

Large-size silicon, photoresist and other integrated key circuit materials, solar cell materials, and lithium-ion battery materials

Lithium-ion power battery materials, functional information materials, marine engineering materials, energy saving and environmental protection materials, and advanced rail transportation materials.

Special metal functional materials, high-performance structural materials, functional polymer materials, special inorganic non-metallic materials, and advanced composite materials.

Advanced basic materials such as high-quality steel materials, novel light alloy materials, industrial ceramics, and functional glass materials. Key strategic materials such as high temperature and corrosion resistant alloys, high performance fibers and composite materials, advanced semiconductor materials, and biomedical applications materials. Cutting-edge materials such as graphene, additive manufacturing materials, smart materials, and metamaterials.

Advanced metal materials, advanced organic materials, advanced inorganic non-metallic materials, advanced composite materials, and cutting-edge materials.

Advanced structural material technology, advanced functional material technology, transformational material development, and novel green manufacturing technologies.

High-strength light-weight alloys, high-performance fibers, special alloys, advanced inorganic non-metallic materials, high-quality special steels, novel display materials, battery materials, green printing materials, graphene materials, nanomaterials, smart materials, bionic materials, metamaterials, low-cost additive manufacturing materials, novel superconducting materials, materials for extreme environments such as aerospace, deep-sea and deep-land, as well as other special materials such as rare earth metals, tungsten, molybdenum, vanadium, titanium, and lithium. 


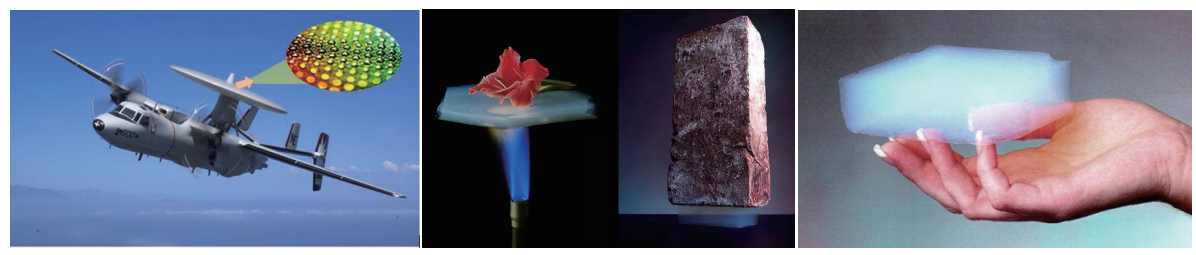

Fig. 1. Metamaterials and their uses.
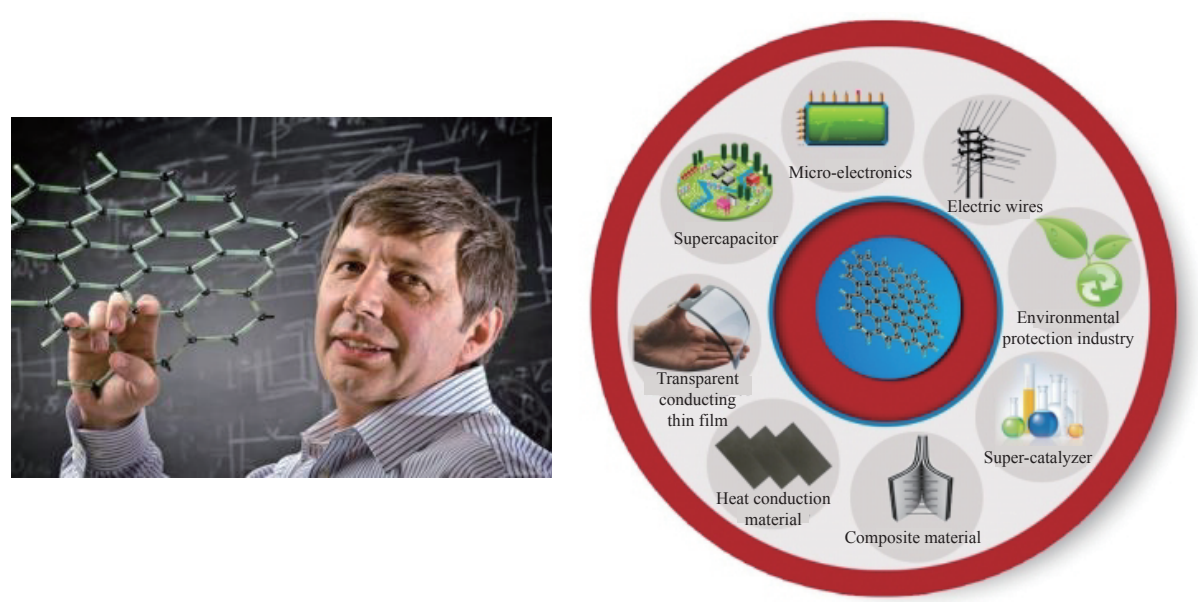

Fig. 2. Graphene-related materials and their use.

that of 2014 [11]. The photovoltaic power generation industry continues to grow and new installed capacity reached $34.54 \mathrm{GW}$, with a cumulative installed capacity reaching $77.42 \mathrm{GW}$ in 2016, which both ranks first worldwide [12]. The semiconductor lighting industry has developed a relatively complete R\&D and industrial system, from upstream epitaxial material production and chip manufacturing to midstream device packaging and downstream integrated applications. The output value of the semiconductor lighting industry reached 521.6 billion yuan in 2015, a year-over-year increase of $22.8 \%$ [13]. The scale of biomedical materials and products continue to grow with market sales reaching nearly 144 billion yuan in 2015, with an annual growth rate exceeding $17.2 \%$ [14]. The output of steel, as an indispensable pillar material in construction, was $1.138 \times 10^{9}$ tons in 2016, a year-over-year increase of $2.3 \%$. Special steel production increased by $10.52 \%$ compared to the same period last year. The total output of non-ferrous metals reached $5.283 \times 10^{7}$ tons, a year-over-year increase of $2.46 \%$. Among them, the output of copper and aluminum reached $2.095 \times 10^{7}$ and $5.796 \times 10^{7}$ tons, a year-over-year increase of $12.53 \%$ and $9.72 \%$, respectively.

\subsection{Emerging role of critical basic materials for important national strategies}

With further improvements in environmental protection and the requirements for green and low-carbon processes, China has implemented a strategy for energy conservation and emission reduction to gradually change the traditional model of high in-
Table 2. China's new material industry scale from 2010 to 2016.

\begin{tabular}{lc}
\hline Year & New material industry scale/ Billion yuan \\
\hline 2010 & 6500 \\
2011 & 8000 \\
2012 & 10000 \\
2013 & 12500 \\
2014 & 16000 \\
2015 & 19000 \\
2016 & 25000 \\
\hline
\end{tabular}

put, consumption, pollution, and low efficiency. China has made unremitting efforts to increase the efficiency of resource and energy use and reduce environmental pollution in manufacturing processes [15]. In the process of industrial transformation, the production of critical basic materials has been adjusted and the development of environmental-friendly materials has been increasing. The use and promotion of lightweight structural materials such as aluminum, titanium, and magnesium have become increasingly prominent in the energy, resource, and environmental industries. Self-developed high efficiency and energy-saving aluminum electrolytic tanks with novel cathode structures have greatly reduced energy consumption and made outstanding contributions to energy conservation. Key technical issues concerning special steel production have been overcome, solving the problems associated with the production process and significantly reducing unit production costs [16,17]. Carbon fiber composite materials have been applied in the aviation, which 
effectively reduced equipment weight, fuel consumption, emissions, and operating costs [18]. A next-generation chemical fiber recycling system characterized by high quality, multi-functionality and low energy consumption has been established through recycling technology innovation. Recycling systems for waste textiles and plastics have been continuously developed and improved. Chemical fiber regeneration and recycling as well as raw material composition have been refined, which has increased the ratio of high-quality recycled textiles.

Critical basic materials have made significant contributions to the smooth implementation of major projects to improve people's livelihood, environmental protection, and develop next-generation information technology. A new building material industry has developed in the model combining self-development with national major projects, which provide important support for green buildings, building energy conservation, old city reconstruction, housing projects, new rural construction, disaster prevention and reduction, and post-disaster reconstruction [19]. Novel energy materials, such as nickel-metal hydride batteries, lithium-ion power batteries, and fuel cells, have provided technological advancement, which has promoted the development of electric vehicles. Electric vehicles were used in the 2008 Olympic Games, the Shanghai World Expo, and the Ten Cities Thousands Electric Cars Project, which demonstrated the development of new energy sources with the potential to reduce environmental pollution [20]. Microelectronics technology continues to improve, which has effectively supported the smooth implementation of major scientific and technological projects during the 12th Five-Year Plan, and promotes the healthy domestic development of integrated circuits and information industries. The steel industry has combined research, development, production, and application and has overcome a number of technical difficulties. The strength, toughness, and plasticity of steel have been continuously improved. The varieties and quality of major high-end steels have effectively supported the development of major national projects and high-end equipment manufacturing, as shown in Fig. 3 [21,22].

Although significant progress has been made in the research, development, and industrialization of critical basic materials in China, a large gap remains between China and developed countries, and there are still some contradictions and problems in commonly used development processes [23,24]. First, original innovation capacity is insufficient, and the basic support system is not perfect. China's critical basic materials have not been incorporated into material brands and systems with independent intellectual property rights. National and industrial standards for basic raw materials, design specifications, and material process quality control are also incomplete. In addition, an industry-standard open database for material structure design, manufacturing, and evaluation has not been developed. Common technology R\&D capability is not strong, and the self-sufficiency rate of high-end products is insufficient. In most industries in China, common technology R\&D is absent. Common and frontier technology R\&D lacks proper resources and continuous effective investment, making it impossible to support independent technology innovation. The lack of R\&D has become a bottleneck that restricts the adjustment and upgrading of China's industrial structure and has decreased industrial competitiveness. In addition, the top-level design and overall coordination is lacking, and instead low-level redundant construction is more common. Although a large amount of material industry plans from the national to local level have been released, some regions have not considered their own conditions and advantages and have not made scientific advances or reasonably positioned themselves for efficient labor division. In some industrial fields, serious convergence phenomena including homogenous layouts, mainline-missing development, and low-level competition swirl exist [2]. The distribution of resources is fragmented, and the industrial chain is incomplete. At present, the number of key basic material enterprises in China is large but scattered. The number of

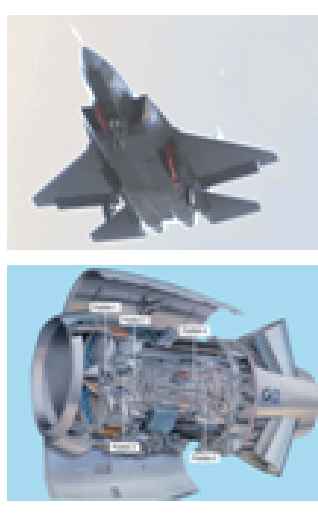

Aero-engine
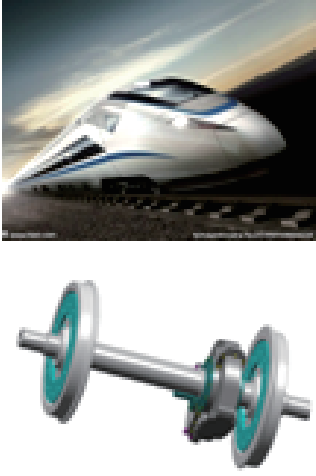

Wheel sets of high-speed trains
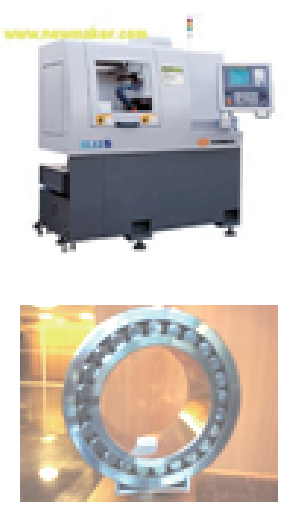

High-speed and high-precision machine tools
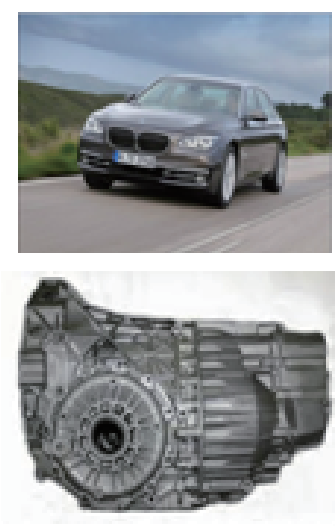

Automatic gearbox of vehicles

Fig. 3. Typical application of critical steel materials. 
backbone enterprises with international competitiveness is small, the level of industry scale benefits is low, price control ability is weak, and access to the international market needs improvement. Some critical basic material industry supply chains are missing, coordination and supporting services are delayed, and the trend of agglomeration development has not been formed. Upstream development lags behind, and downstream applications face tremendous upgrade pressure. In addition, links between upstream and downstream industries are not smooth, which is detrimental to the healthy development of the critical basic material industry. The concept of green and low-carbon industry is also weak, and energy saving and environmental protection must be strengthened. Some critical basic material manufacturers in China have weak green and low-carbon concepts and only care about development with low investment, short cycles, and rapid benefits, which often leads to low-end products, enormous waste, and severe environmental pollution.

\section{Development of foreign critical basic materials}

\subsection{Macro guide to critical basic materials}

Since the beginning of the 21 st century, countries around the world have paid close attention to critical basic materials. They have formulated corresponding plans and issued policies regarding $\mathrm{R} \& \mathrm{D}$, markets, and industrial environments to comprehensively strengthen and promote the development of critical basic materials [2]. More than 20 developed countries and emerging economies have developed material-related emerging industry development strategies and have initiated more than 100 special programs. The United States released the Strategy for American Innovation in 2009 and updated it in 2011 and again in 2015. One of the six key elements in this strategy for sustaining the innovation ecosystem is catalyzing breakthroughs for national priorities by promoting clean energy technologies and advancing energy efficiency, tackling grand challenges, targeting disease with precision medicine, reducing fatalities with advanced vehicles, building smart cities, developing breakthrough space capabilities, and pursuing new frontiers in computing. These strategic objectives all involve critical basic materials. The European Union (EU) formulated the Europe 2020 Strategy in March 2010 to emerge stronger from the economic and financial crisis, meet global challenges, and turn the EU into a smart, sustainable, and inclusive economy delivering high levels of employment, productivity, and social cohesion. Europe 2020 puts forward three mutually reinforcing priorities: smart, sustainable, and inclusive growth. Germany released the 2020 High-tech Strategy for Germany: Idea.Innovation Growth in 2010. The United Kingdom Department for Business, Innovation, and Skills (BIS) released the Innovation and Research Strategy for growth in 2011. Japan released the New Growth Strategy based on the Economic Revival Strategy in 2015. South Korea released the National Strategy for Green Growth, Five-Year Action Plan, and the New Growth Power Planning and Development Strategy in 2009. Besides these strategies, countries all over the world have also developed special plans and action plans to support priority areas. The United States, EU, and Japan have launched special plans such as the Smarter Planet, the Federal Big Data Research and Development Strategic Plan, the Internet of Things Strategic Research Roadmap, the UK Digital Strategy, and the ICT Hatoyama Plan. Emerging economies such as Brazil, India, and Russia have adopted catch-up strategies and are developing special plans for new energy materials, energy-saving and environment-friendly materials, nanomaterials, biomaterials, medical and health materials, and information materials [25] to seize a place in the future international competition. The above plans all regard critical basic materials as a key development direction, development area, and important aspect of industrial development and use critical basic materials as an important support for the next industrial revolution (Table 3 ).

\subsection{Critical basic material technology development breakthrough to promote industrial transformation}

The rapid development of high-tech industries promotes the development of critical basic materials, and vice versa [2]. Silicon has played an important role in continuous cost reduction, chip integration, and information-processing speed increase. Currently, the $300 \mathrm{~mm}$ silicon chip can meet the integrated circuit requirements of the $14 \mathrm{~nm}$ nodes, and has good long-term development prospects (Fig. 5) [26]. The promising $450 \mathrm{~mm}$ silicon chip samples has also been produced. The important R\&D breakthrough of low-temperature co-fired ceramic (LTCC) technology has made integrating large passive electronic components in the same substrate possible [27]. To date, the LTCC technology has mainly been used as an interconnected packaging method for multi-chip modules (MCM/C), but it can also be used in non-circuit applications such as fuel cells, sensors, and electronic components. Over the past few decades, an increasing number of industries have emerged with the continuous extension of advanced materials technology research. For example, the development of compound semiconductor materials, including gallium nitride, has given rise to semiconductor lighting technology [28]. White light-emitting diodes (LEDs), which have far more luminous efficacy than incandescent or fluorescent lamps, have brought revolutionary changes to the lighting industry. The continuous improvement of solar cell conversion efficiencies has greatly promoted the development of new energy industries. High-tech structural materials, such as magnesium and titanium alloys, have achieved breakthroughs in processing technology with continuous cost reductions, which has expanded the research and application focus from aviation, aerospace, and military fields to value-added residential applications [29-32]. The development of clinical diagnostic materials and devices 
Table 3. International critical basic materials related development strategies and plans.

\begin{tabular}{|c|c|c|}
\hline Country & Development plan & New materials related fields \\
\hline United States & $\begin{array}{l}\text { A National Strategic Plan for Advanced Manufacturing, A Framework for } \\
\text { Revitalizing American Manufacturing, Advanced Manufacturing Partnership } \\
\text { (AMP), Nanotechnology Signature Initiatives (NSI), National Bioeconomy } \\
\text { Blueprint, EV Everywhere Grand Challenge Blueprint, Smarter Planet, The } \\
\text { Federal Big Data Research and Development Strategic Plan, Next Generation } \\
\text { Lighting Initiative (NGLI), and Strategies for Wide Bandgap, Inexpensive } \\
\text { Transistors for Controlling High-Efficiency Systems (SWITCHES). }\end{array}$ & $\begin{array}{l}\text { New energy materials, biological and } \\
\text { pharmaceutical materials, environment- } \\
\text { friendly materials, nanomaterials, advanced } \\
\text { manufacturing, next generation information } \\
\text { and network technology, and electric vehicle } \\
\text { related materials, material genomes, and wide } \\
\text { bandgap semiconductor materials. }\end{array}$ \\
\hline European Union & $\begin{array}{l}\text { Strategic Energy Technology Plan, A European Union New Energy Strategy } \\
\text { 2020, Internet of Things Strategic Research Roadmap, Europe } 2020 \text { Strategy, } \\
\text { Innovation for Sustainable Growth: A Bioeconomy for Europe, Horizon 2020, } \\
\text { EU Rainbow Project, OLED100.eu, and Flagship Plan. }\end{array}$ & $\begin{array}{l}\text { Low-carbon industrial materials, information } \\
\text { technology (focus on the internet of things) } \\
\text { related materials, biomaterials, and graphene. }\end{array}$ \\
\hline Russia & $\begin{array}{l}\text { Energy Strategy by 2030, Science and Technology Development by 2020, } \\
\text { National Energy Development Plan, A Comprehensive Plan for the Development } \\
\text { of Biotechnology by 2020, An Information Technology Industry Development } \\
\text { Plan by 2018, National Electronics and Radio Electronics Industry Development } \\
\text { Special Program by 2025, and Priorities for Science and Technology } \\
\text { Development by } 2030 .\end{array}$ & $\begin{array}{l}\text { New energy materials, energy-saving } \\
\text { and environment-friendly materials, } \\
\text { nanomaterials, biomaterials, medical and } \\
\text { health materials, and information materials. }\end{array}$ \\
\hline Germany & $\begin{array}{l}\text { Energy Strategy 2050: Clean, Reliable and Economical Energy System, High- } \\
\text { tech Strategic Action Plan, } 2020 \text { High-tech Strategy, } 2030 \text { Bio-economic } \\
\text { National Research Strategy, National Electric Vehicle Development Plan, } \\
\text { Industry } 4.0 \text { (Fig. 4) }\end{array}$ & $\begin{array}{l}\text { Renewable energy materials, biomaterials, } \\
\text { and electric vehicle related materials. }\end{array}$ \\
\hline United Kingdom & $\begin{array}{l}\text { The UK Low Carbon Transition Plan, the UK Renewable Energy Strategy, } \\
\text { Technology and Innovation Center Program, the Marine Industries Growth } \\
\text { Strategy, UK Synthetic Biology Roadmap, and The Future of Manufacturing: A } \\
\text { New Era of Opportunity and Challenge for the UK. }\end{array}$ & $\begin{array}{l}\text { Low carbon industrial materials, value-added } \\
\text { manufacturing related materials, biomaterials, } \\
\text { and marine materials. }\end{array}$ \\
\hline France & $\begin{array}{l}\text { Roadmap for Environmental Protection Reform, Investment Plan for the Next } \\
\text { Decade, and Internet: Outlook } 2030 .\end{array}$ & $\begin{array}{l}\text { Renewable energy materials, environment- } \\
\text { friendly materials, information materials, and } \\
\text { green car related materials. }\end{array}$ \\
\hline Japan & $\begin{array}{l}\text { New Growth Strategy, New National Energy Strategy, Basic Energy Plan, } \\
\text { National Declaration of Cutting-edge IT Creation, Next-generation Automobile } \\
\text { Plan, and Marine Policy. }\end{array}$ & $\begin{array}{l}\text { New energy materials, energy-saving and } \\
\text { environment-friendly materials, information } \\
\text { materials, and new vehicle related materials. }\end{array}$ \\
\hline South Korea & $\begin{array}{l}\text { New Growth Power Plan and Development Strategy, Comprehensive Nuclear } \\
\text { Energy Promotion Plan, Korea 's IT Future Strategy, National Integration } \\
\text { Technology Development Plan, Third Science and Technology Basic Plan, and } \\
\text { the } 21 \text { st Century Light Plan. }\end{array}$ & $\begin{array}{l}\text { Renewable energy materials, information } \\
\text { materials, and nanomaterials. }\end{array}$ \\
\hline India & $\begin{array}{l}\text { National Action Plan on Climate Change, National Solar Energy Plan, Twelfth } \\
\text { Five Year Plan (2012-2017), Science, Technology and Innovation Policy } 2013 .\end{array}$ & New energy materials and biomaterials. \\
\hline Brazil & $\begin{array}{l}\text { Low-carbon Strategic Plan, 2012-2015 National Science and Technology } \\
\text { Innovation Strategy, and Science and Technology Innovation Action Plan. }\end{array}$ & $\begin{array}{l}\text { New energy materials, green cars, civil } \\
\text { aviation, and modern bio-agriculture related } \\
\text { materials }\end{array}$ \\
\hline South Africa & $\begin{array}{l}\text { The Green Book of National Strategy, New Industrial Policy Action Plan, } 2030 \\
\text { Development Plan, and Comprehensive Resource Plan. }\end{array}$ & $\begin{array}{l}\text { New energy materials, biopharmaceutical } \\
\text { materials, and aerospace related materials. }\end{array}$ \\
\hline
\end{tabular}

based on molecules and genes has made the early detection and treatment of major diseases possible, such as liver cancer. The R\&D of interventional devices has generated minimally invasive and interventional techniques, which have significantly reduced the death rate from cardiovascular diseases [33,34].

\subsection{Green processes and low carbon intensity as important standards for critical basic materials development}

The rise of new renewable energy, such as solar, nuclear, and bio-energy, has caused major changes in power, construction, automotive, and communications industries $[35,36]$. This has led to the development of a series of manufacturing and resource processing industries, including wind turbine manufacturing, photovoltaic modules, and poly-silicon industries. Over the long term, these industries can promote the development and production of transportation and terminal products, such as smart grids and electric vehicles. Developed Western countries have passed legislation to promote the development of energy-efficient buildings and photovoltaic power generation. At present, $80 \%$ of the insulated glass in Europe uses Low-E glass, with the penetration rate of Low-E glass in the United States reaching $82 \%$ [37]. The energy saving principle of Low-E glass is described further in Fig. 6. Enhancing structural material toughness and temperature adaptability, extending material life, and implementing material composite design can reduce costs and increase material quality. For example, T800 carbon fiber has a compressive strength (CAI) of $350 \mathrm{MPa}$ can be used at temperatures above $400{ }^{\circ} \mathrm{C}$, which 

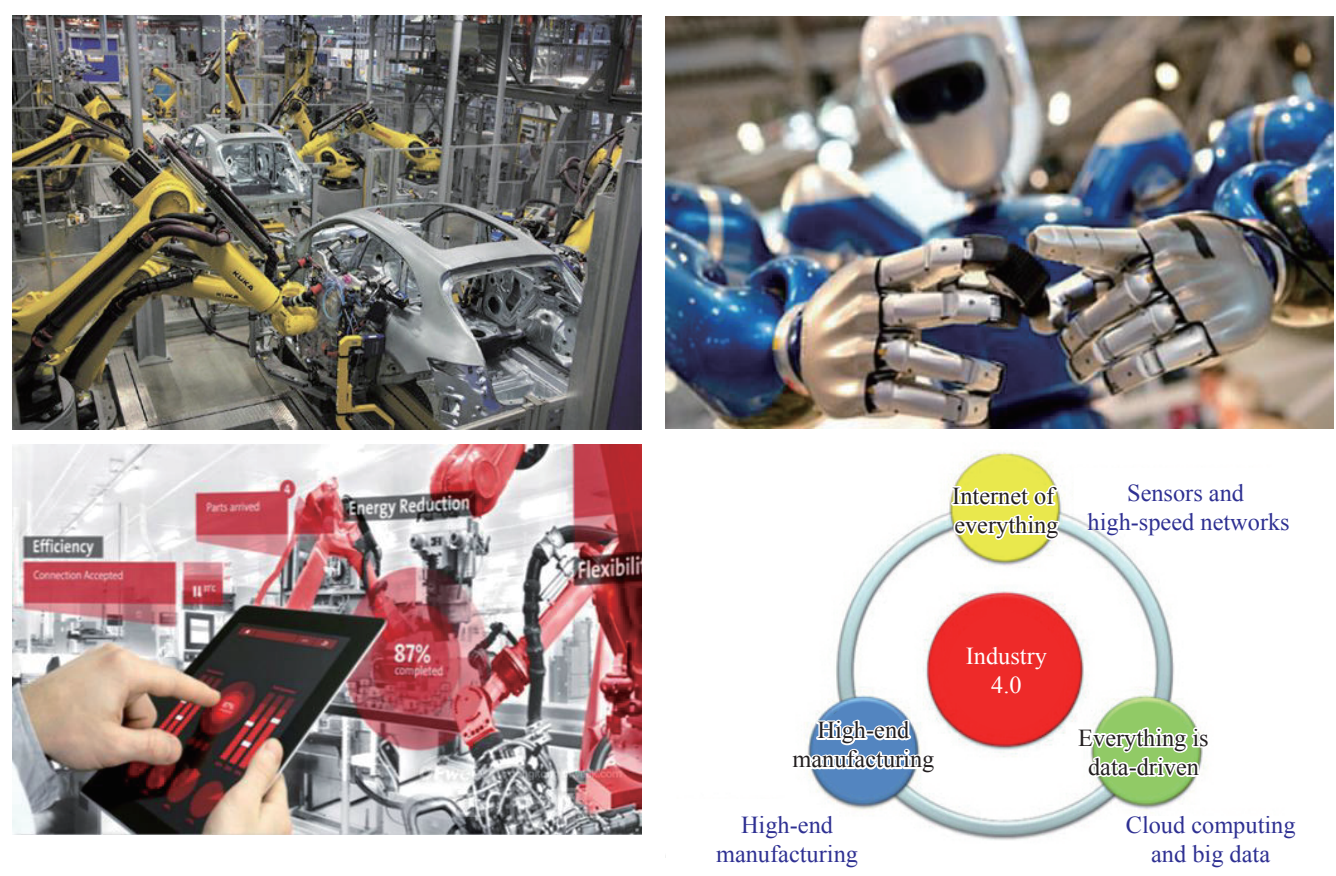

Fig. 4. Industry 4.0

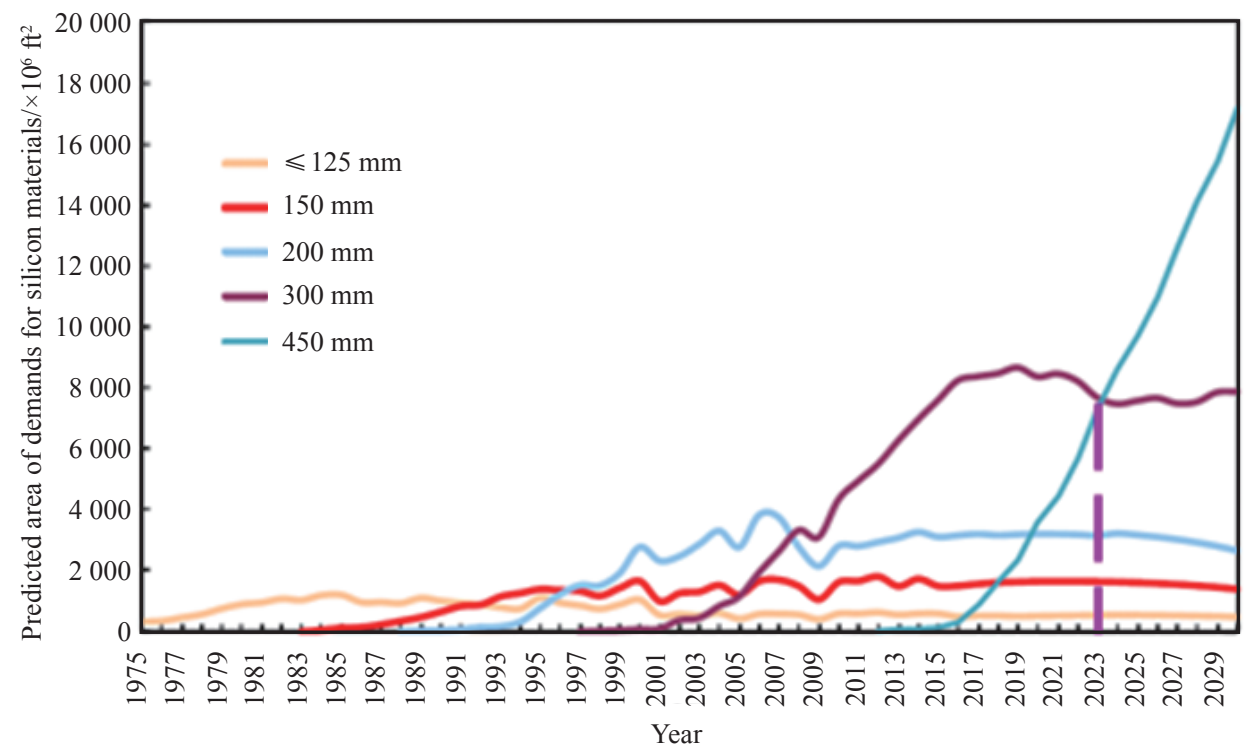

Fig. 5. Silicon materials demand predication.

has opened a large number of applications in the main structural parts of large aircraft and missiles. Functional materials have also been developed towards miniaturization, multi-functionalization, module integration, and intelligence to improve material performance [38]. The fusion of nanotechnology and advanced manufacturing technologies will result in smaller, smarter, more integrated, and more functional products.

\subsection{Changing the R\&D model of critical basic materials}

Since the beginning of the 21 st century, developed coun- tries have gradually realized that traditional material research methods which rely on trial and error cannot keep up with the rapid pace of industrial development, and may even become a bottleneck restricting technological progress. Therefore, an urgent need has arisen for innovative material R\&D methods to accelerate the progress from R\&D to application. The U.S. government launched the Material Genome Initiative (MGI) in 2011 as an important part of the Advanced Manufacturing Partnership (AMP). The MGI aims to decrease the time and cost of material discovery to deployment, develop high-end manufacturing based on advanced materials, and maintain the American advantage 

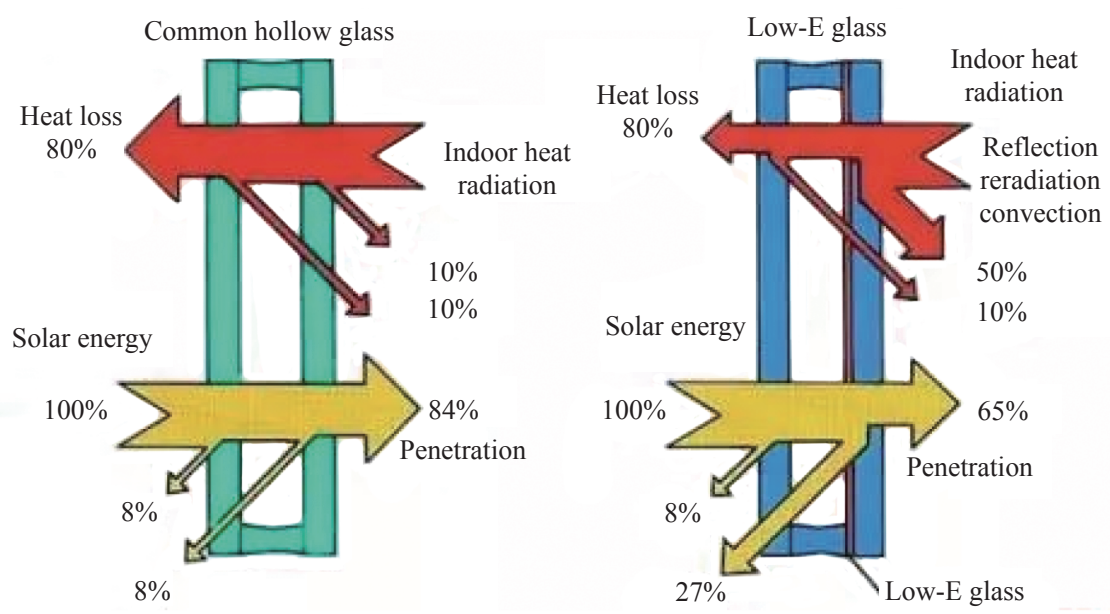

Fig. 6. Energy saving principles of Low-E glass.

in core science and technology [39-41]. The four MGI strategic goals are: 1) enable a paradigm shift in materials development and use; 2) integrate experiments, computation, and theory; 3 ) facilitate access to materials data; 4) equip the next-generation materials workforce. An analogy between the MGI and Human Genome Project is shown in Fig. 7. Besides the United States, other countries have initiated similar scientific plans to reform the material R\&D model. The EU launched the Accelerated Metallurgy (ACCMET) program in response to the demand for high-performance materials such as lightweight, high-temperature superconducting, magnetic, thermomagnetic, thermoelectric, and phase change memory storage materials [2].

\section{Development focus of China's critical basic materials}

According to the international development trends as well as the demands of China's growing economy and national defense industry, China has selected key critical basic materials and aims to accelerate major technological breakthroughs, create a suitable environment for industrial development, promote industrial upgrading, and form good industrial ecology.

\subsection{Development goals}

\subsubsection{Development goals by 2020}

China's critical basic materials development goals by 2020 are as follows: 1) master the core technology, achieve breakthroughs with respect to large-scale production technology, improve system integration technology, and shorten the gap with the world leaders; 2) establish a high-level business-oriented material R\&D platform and strengthen engineering technology research; 3 ) promote the localization of critical basic materials and achieve a $70 \%$ self-sufficiency rate; 4) ensure mass production to meet the needs of major national projects and national security.

Muman Genome Project
The genetic arrangement of the human body determines $\begin{aligned} & \text { Material microstructure and atom arrangement determines the } \\ & \text { properties of the material } \\ & \text { its function }\end{aligned}$

Fig. 7. Analogy between the Material Genome Initiative and the Human Genome Project 


\subsubsection{Development goals by 2025}

China's critical basic materials development goals by 2025 are as follows: 1) make the overall critical basic materials industry achieve the world leaders' level; 2) achieve large-scale green manufacturing and recycling; 3 ) build a critical basic materials innovation system and achieve self-sufficiency in the supply of most critical basic materials; 4) meet the needs of the national economy, national security, and socially sustainable development; 5) achieve the transition from quantity to quality.

\subsection{Development priorities}

The development priorities of critical basic materials are summarized in Table 4.

\section{Policy suggestions for accelerating the development of China's critical basic materials}

\subsection{Accelerate the R\&D system}

We should closely follow the national development strategy, strengthen top-level design, and rationally design the R\&D system for critical basic materials, paying attention to the cutting-edge materials in the R\&D stage, making appropriate arrangements for advancement, establishing an industry-standard open database for material structure design, manufacturing, and evaluation, developing a material standard system with Chinese characteristics which is also in line with international standards, and addressing the engineering problems in the development of critical basic materials industries.

\subsection{Improve the industrial development environment}

We should accelerate the formulation of guidance catalogs and investment-oriented opinions regarding the development of key basic materials industries and improve the industrial, innovation, and capital chains. Exerting the role of market allocation of resources, scientific guidance, and rational investment should be emphasized. Coordination of the country's focused support for key basic materials industries should be highlighted to assist in the healthy growth of small- and medium-sized enterprises producing critical basic materials and create an industrial ecological environment with international competitiveness.

\subsection{Promote the coordinated development of quality and efficiency}

We should improve the product quality and stability of critical basic materials, reduce production costs, and enhance industrial support capabilities. Focusing on the country's major project construction needs, we should strengthen collaborative innovation in production, education, and research, and improve the consistency and service reliability of key basic materials. Promotion of supply chain establishments and collaboration be-

Table 4. Development priorities of critical basic materials.

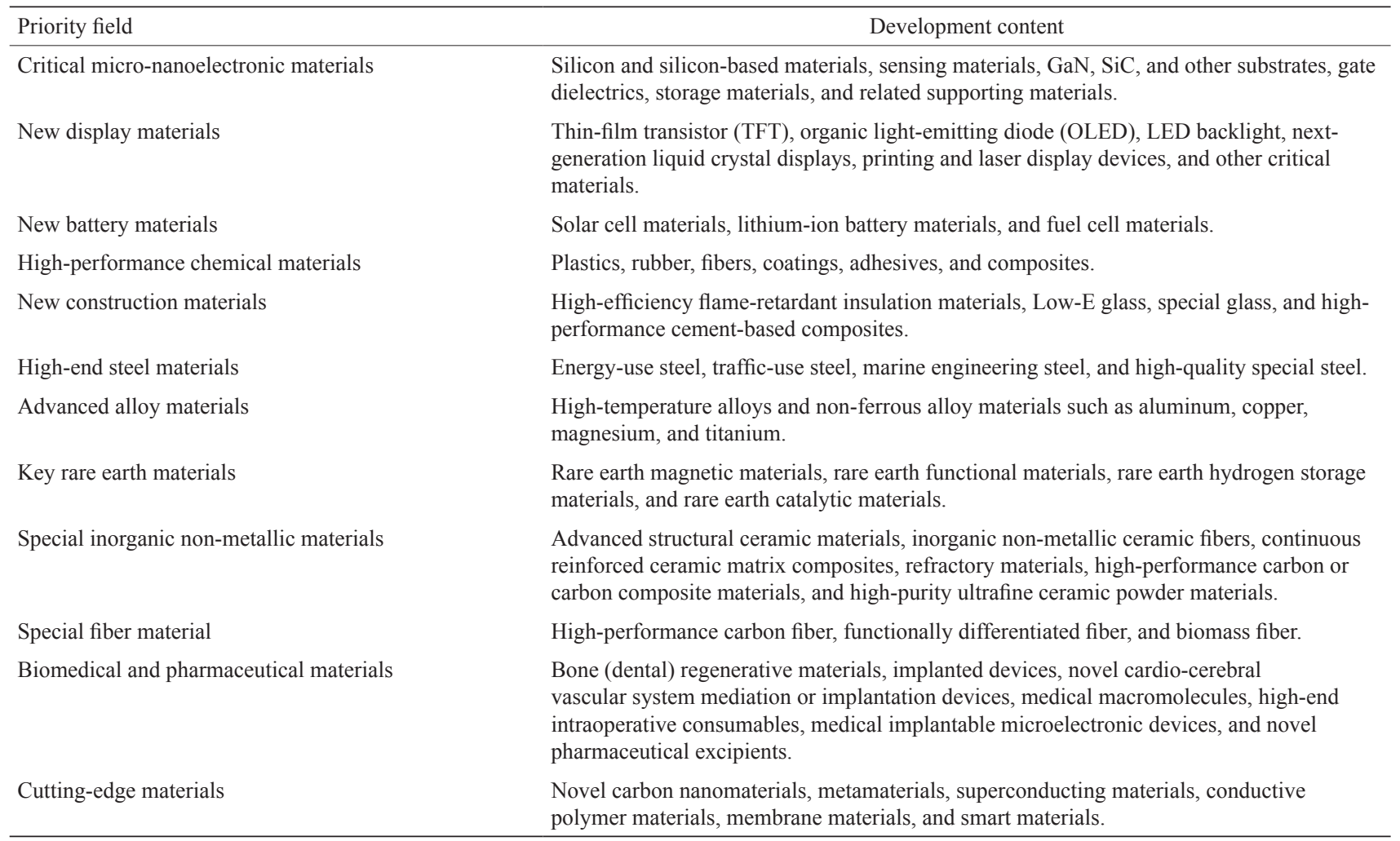


tween advantageous critical basic material companies and highend equipment manufacturing enterprises should be emphasized. In addition, the optimization of a variety of structures, promoting product integration into global high-end manufacturing supply chains, and improving the international competitiveness of critical basic materials in China are essential.

\subsection{Strengthen policy support}

We should increase financial and taxation policies to support critical basic materials, establish and improve standardized risk investment operations, risk aversion, and exit mechanisms, and form a healthy system that encourages domestic use of critical basic materials. In addition, improving tax policies that support innovation and creating a good investment environment to prevent a wholesale invasion of investment and the phenomenon of investment overlapping are important. Implementing the deduction of $R \& D$ expenses and preferential income tax policy for high-tech enterprises is also essential.

\subsection{Promote talent team construction}

We should implement innovative talent development strategies, foster core talents and teams, encourage talent at home and abroad, and promote enterprises to actively cultivate independent innovative talents. At the same time, we should also support the role of industry associations, research institutes, and universities, and jointly establish a key basic materials industry expert system to strengthen direct communication and exchange of material R\&D, production, and application of knowledge. The critical basic materials industry expert system should provide advice on the status quo, development trends, and key issues of concern for the key basic materials.

\section{References}

[1] Ministry of Industry and Information Technology of the PRC. Guidelines for implementation of strong industrial engineering (2016-2020) [R]. Beijing: Ministry of Industry and Information Technology of the PRC, 2016. Chinese.

[2] Tu H L, Zhang S R, Li T F. Research on development strategies for China's advanced materials industry [J]. Strategic Study of CAE, 2016, 18(4): 90-100. Chinese.

[3] Tu H L, Zhou J, Zhang G. The growth technology for $300 \mathrm{~mm}$ single crystal silicon [J]. Microelectronic Engineering, 2001, 56(1): 77-82.

[4] Wang J Y, Wu Y C. Progress of the research on photo electronic functional crystals [J]. Materials China, 2011, 29(10): 1-12. Chinese.

[5] Zhang X M. Basic research on high performance aluminum alloy materials for aviation [J]. China Science and Technology Achievements, 2016, 17(17): 18-19. Chinese.

[6] Chang H, Zhou L, Wang X D. Development and future of Chinese titanium industry and technology [J]. Journal of Aeronautical Ma- terials, 2014, 4(4): 38-43. Chinese.

[7] Zhou J. Some ideas on the combination of metamaterials and natural materials [J]. Advanced Materials Industry, 2014 (9): 5-8. Chinese.

[8] Pu J B, Wang L P, Xue Q J. Progress of tribology of graphene and graphene-based composite lubricating materials [J]. Tribology, 2014, 34(1): 93-112. Chinese.

[9] Shi C X. Reflections on the construction of China's "new material industry system" [J]. Journal of Engineering Studies, 2013, 5(1): 5-11. Chinese.

[10] Xu K D, Ren Z M, Li C J. Progress in application of rare metals in super alloys [J]. Rare Metals, 2014, 33(2): 111-126.

[11] Xu N P. The development and prospect of the research on film field in China [R]. Tianjin: The 6th national symposium of film and film process, 2008. Chinese.

[12] National Energy Administration of the PRC. Photovoltaic power generation statistics for 2016 [EB/OL]. (2017-02-04) [2017-03-16]. http://www.nea.gov.cn/2017-02/04/c_136030860.htm. Chinese.

[13] China Soled State Lighting Alliance. The annual white paper on the development of semiconductor lighting industry in 2016 [R]. Beijing: China Soled State Lighting Alliance, 2016. Chinese.

[14] Ting F X. Current status and development trend of biomedical materials in China [J]. China Medical Device Information, 2013 (8): 1-5. Chinese.

[15] Du X W, Yang B, Liu X L, et al. Decoupling analysis of China's economic development, energy consumption and carbon dioxide emission [J]. China Population, Resources and Environment, 2015, 25(12): 1-7. Chinese.

[16] Gan Y, Li G Y, Ma M T, et al. Development of advanced compact steel process and deep working technology for high-strengthductility auto-parts [J]. Steel Rolling, 2015, 32(4): 1-11. Chinese.

[17] Xie J X, Liu X F, Zhou C, et al. Intelligentization of materials processing technology $[\mathrm{J}]$. Chinese Journal of Mechanical Engineering, 2005, 41(11): 8-14. Chinese.

[18] Xing L Y, Bao J W, Li S M, et al. Development status and facing challenge of advanced polymer matrix composites [J]. Acta Materiae Compositae Sinica, 2016, 33(7): 1327-1338. Chinese.

[19] Yao Y, Wang X, Yan B L, et al. The research on heavy metal ionscuring and its influence on the cement hydration process $[\mathrm{J}]$ Bulletin of the Chinese Ceramic Society, 2012, 31(5): 1138-1144. Chinese.

[20] Lu S G, Shi Q T, Tang H B. Mathematical analysis and numerical simulation for thermo-stress in a square lithium-ion battery [J]. Journal of Automotive Safety and Energy, 2014, 5(3): 298-303. Chinese.

[21] Yin R Y. Process engineering and manufacturing process [J]. Iron \& Steel, 2014, 49(7): 15-22. Chinese.

[22] Chinese Academy of Engineering. Strategy research of special steel in advanced equipment manufacturing application advisory report [R]. Beijing: Chinese Academy of Engineering, 2012. Chinese.

[23] Chinese Academy of Engineering. The present situation and development strategy of nonferrous rare metal materials in China (2010-2012) [R]. Beijing: Chinese Academy of Engineering, 2012. Chinese.

[24] Tu H L. Research report on the cultivation and the development of new materials industry $[\mathrm{M}]$. Beijing: China Science Publishing \& 
Media Ltd (CSPM), 2014. Chinese.

[25] China Institute of Engineering Development Strategy. Development report of China's strategic emerging industries (2014) [M]. Beijing: China Science Publishing \& Media Ltd (CSPM), 2013. Chinese.

[26] Tu H L. $450 \mathrm{~mm}$ silicon wafers are imperative for Moore's law but maybe postponed [J]. Engineering, 2015, 1(2): 162-163.

[27] Li L T. Research progress of functional ceramic materials [J]. Functional Materials Information, 2005, 2(1): 10-14. Chinese.

[28] The development course and future outlook of semiconductor lighting technology industry in China [J]. Electronics World, 2016 (6): 7. Chinese.

[29] Cui Y, Li Y, Luo K, et al. Research progress on biomedical NiFree Ti based shape memory alloys [J]. Rare Metal Materials and Engineering, 2010, 39(9): 1682-1686. Chinese.

[30] Li Z P. Major Advancement and development trends in study of hotwall microwave-transparency mechanisms and high-temperature microwave-transparent materials [J]. Materials China, 2013, 32(4): 193-202. Chinese.

[31] Chen X B, Zhang B Y, Li B T. Low temperature cure high performance composites [J]. Journal of Materials Engineering, 2011 (1) 1-6. Chinese.

[32] Xu Q Y, Pan D, Yu J, et al. Application of numerical simulation technology in superalloy single crystal blade of aeroengine [J]. Aeronautical Manufacturing Technology, 2011 (4): 26-31. Chinese.
[33] Zhang X D, Wang B T. The rise of biological materials science and industry in China [J]. Advanced Materials industry, 2009 (10): 92-95. Chinese.

[34] Wang Y J, Du C, Zhao N R, et al. Biomimetic artificial bone repair materials: A review [J]. Journal of South China University of Technology (Natural Science Edition), 2012, 40(10): 51-58. Chinese.

[35] Li G X. Coming challenge and opportunity to the nuclear fuel cycle industry of China [J]. Uranium Geology, 2008, 24(5): 257-267. Chinese.

[36] Tan T W. The development trend of green bio-manufacturing industry [J]. Biotechnology \& Business, 2015 (6):13-15. Chinese.

[37] Nie Z R, Gao F, Gong X Z, et al. Recent progress and application of materials life cycle assessment in China [J]. Progress in Natural Science: Materials International, 2011, 21(1): 1-11.

[38] Xu H B, Gong S K, Jiang C B, et al. Solid-state phase transformations and their applications in special functional materials $[\mathrm{J}]$. Materials China, 2011, 30(9): 1-13. Chinese.

[39] Chen L Q. The materials genome initiative and advanced materials [J]. Engineering, 2015, 1(2): 169.

[40] Gerbrand C, Kristin P. How supercomputers will yield a golden age of materials science [J]. Scientific American, 2013 (3): 36-40.

[41] Jain A, Ong S P, Hautier G, et al. The materials project: A materials genome approach to accelerating materials innovation [J]. APL Materials, 2013, 1(1): 2166-2176. 